\title{
The Revenge of the Redwoods? Reconsidering Property Rights and the Economic Allocation of Natural Resources
}

\author{
Daniel S. Levy† \\ David Friedmant†
}

One of the most influential ideas in the field of law and economics has been that the allocation of property rights may have little effect on the ultimate use of property. ${ }^{1}$ Indeed, Ronald Coase was awarded the 1991 Nobel Prize in economics partially in recognition of his contribution to this line of thought. A rich body of literature now claims that when certain highly stylized conditions are met, the assignment of property rights will not affect the ultimate allocation of goods among rational actors. ${ }^{2}$ Under such conditions, the literature argues, private bargaining, not judicial or regulatory intervention, will lead to the most efficient use of economic resources. ${ }^{3}$

$\dagger$ Senior Associate, Charles River Associates, Boston.

if Fellow, MIT Japan Program; Of Counsel, Tuttle \& Taylor, Los Angeles. Portions of the work related to this article were conducted at RAND and presented to the EPA (ADFRL-3700-4). The specific amenity at issue was visibility in the Grand Canyon. The authors would like to thank James Hammitt, Naihua Duan, Theo Downes-Leguin, Jan Acton, C. David Anderson, Robert Bell, Telis Bertsekas, Dick Buddin, John DiNardo, Franklin M. Fisher, David Galenson, Steve Garber, Jim Hosek, Poorti S. Marino, Chris Maxwell, Mark Ramseyer, K.C. Sheehan, Toni Richards, Sherwin Rosen, Gary Schwartz, Al Williams, and the editors for the insightful comments which they provided freely, and which have been invaluable to us.

1 This idea, which has come to be known as the "Coase Theorem," first appeared in R.H. Coase, The Problem of Social Cost, 3 J L \& Econ 1 (1960).

2 Particularly influential examples include Richard A. Posner, Economic Analysis of Law § 1.1 at 8, § 3.6 at 49-52 (Little, Brown, 4th ed 1992), and William M. Landes and Richard A. Posner, The Economic Structure of Tort Law 29-53 (Harvard, 1987). See also Guido Calabresi and A. Douglas Melamed, Property Rules, Liability Rules and Inalienability: One View of the Cathedral, 85 Harv L Rev 1089, 1094-96 (1972) (noting that economic efficiency does not mean, however, that the same ultimate allocation of goods will result regardless of the initial allocation of property rights, due to wealth effects and other distortions). For a recent review of the literature and application of economic principles in an environmental law context, see Note, Restoration as the Economically Efficient Remedy for Damage to Publicly Owned Natural Resources, 91 Colum L Rev 430 (1991).

3 Most of the theoretical and empirical law-and-economics literature related to the Coase Theorem supports a laissez-faire judicial system. The conditions necessary for an efficient laissez-faire system include: (a) costless negotiation, (b) well-specified property rights, and (c) redistribution that does not affect marginal values. See P.R.G. Layard and 
But despite the influence of conventional law and economics on American jurisprudence, the instances in which it properly applies may be more limited than often is assumed. Even the field's founders recognized that their arguments are valid only subject to several restrictive conditions: allocation and redistribution decisions must not affect marginal values; goods must be freely substitutable; property rights must be well defined and enforceable; and goods must be fungible, which is to say that people must be indifferent as to whether they own one as opposed to another specific item of a given good. ${ }^{4}$ While it may be plausible to suppose that some goods, such as the economists' proverbial bushels of wheat, are completely fungible, it is much less likely that a family home, a limb, or the Grand Canyon have ready substitutes. Owners prize these and similar amenities precisely because they are unique.

Few studies have explored the relationship between legal rights and economic allocation for goods that have no close substitutes. But as American environmental protection efforts expanded in the last decade, environmental valuation issues raised problems for conventional law-and-economics analysis. To implement federal environmental statutes, it became necessary to determine the value of unique natural resources such as national parks, rivers, beaches, and wilderness vistas. However, standard markets and other observable economic behavior rarely reflect the value of environmental goods. Environmental researchers therefore turned to non-behavioral methods of valuing resources, in particular, to survey methods such as contingent valuation, or "CV." CV estimates the value of a good or service, such as a natural resource, by surveying how much a representative sample population values the good or service. ${ }^{5}$

A.A. Walters, Microeconomic Theory 192 (McGraw-Hill, 1978). See also Elizabeth Hoffman and Matthew L. Spitzer, Experimental Law and Economics: An Introduction, 85 Colum L Rev 991, 1010 (1985). As discussed below, this implies that either the income effect must be zero, the substitution effect must be infinite, or both. For a discussion of the implications for judicial roles in settling disputes when such conditions apply, see id at 1009-13; Landes and Posner, Economic Structure of Tort Law at 29-41. The dominant laissez-faire approach has been attacked on the grounds that it is inherently ideological and that the necessary assumptions for its validity are unrealistic. See, for example, Mark Kelman, Consumption Theory, Production Theory, and Ideology in the Coase Theorem, $52 \mathrm{~S}$ Cal L Rev 669, 673-97 (1979); Landes and Posner, Economic Structure of Tort Law at 9-24 (summarizing these criticisms).

4 See, for example, Coase, $3 \mathrm{~J} \mathrm{~L} \mathrm{\&} \mathrm{Econ} \mathrm{at} \mathrm{15;} \mathrm{Calabresi} \mathrm{and} \mathrm{Melamed,} 85$ Farv L Rev at 1093-98.

5 Modern contingent valuation methods evolved from interviews asking respondents to value natural resources. This technique was first proposed in S.V. Ciriacy-Wantrup, 
As researchers developed this new measurement technique, they discovered that the estimated value of a given natural resource could vary by three hundred to nearly two thousand percent, depending on the specific wording of the survey and the implied underlying property rights. ${ }^{6}$ Many commentators have documented this variability and investigated its causes. ${ }^{7}$ Several attempts to reconcile these results with mainstream law-andeconomics theory followed, but none has been completely successful. ${ }^{8}$

Recent theoretical work suggests that part of the observed variance in natural resource valuation arises from the fact that natural resources are often almost pure examples of goods that have no close substitutes, what we will call "less-substitutable" goods. ${ }^{9}$ Economic principles in fact predict that the value of these goods will vary as property rights differ..$^{10}$ Put simply, if the public views itself as the owner of a natural resource, valuation estimates will be much higher than if the public believes that others own the natural resource. Successfully implementing America's burgeoning environmental protection regime therefore requires new analyses appropriate for less-substitutable goods. Furthermore, a theory of less-substitutable good valuation developed for environmental law may stimulate a general reconsideration of the interplay between property rights and economic allocation in American law.

Capital Returns from Soil Conservation Practices, 29 J Farm Econ 1181 (1947), and analyzed more extensively in Ciriacy-Wantrup, Resource Conservation: Economics and Policies (California, 1952). For a comprehensive discussion of the history, application, and theoretical problems with CV, see Robert Cameron Mitchell and Richard T. Carson, Using Surveys to Value Public Goods: The Contingent Valuation Method (Resources for the Future, 1989); Richard C. Bishop and Thomas A. Heberlein, The Contingent Valuation Method, in Rebecca L. Johnson and Gary V. Johnson, eds, Economic Valuation of Natural Resources 80-104 (Westview, 1990).

- For a comprehensive discussion of this divergence, see Edward J. Yang, et al, eds, The Use of Economic Analysis in Valuing Natural Resource Damages 30-32 (National Oceanic \& Atmospheric Administration, 1984) ("NOAA Report"). The NOAA Report shows, for example, that if people have the right to such amenities as a day's saltwater fishing trip, they will demand nineteen times more compensation to sell their right than they would be willing to pay to acquire the right in the first place. Id at 31 . In general, this divergence can range from three to twenty times the lower value. Id at 31,62 .

7 See notes 67-73 and accompanying text.

${ }^{8}$ See notes 74-76 and accompanying text. But see W. Michael Hanemann, Willingness to Pay and Willingness to Accept: How Much Can They Differ?, 81 Am Econ Rev 635 (1991); Richard T. Carson, Constructed Markets, in John B. Braden and Charles D. Kolstad, eds, Measuring the Demand for Environmental Quality 128-30 (Elsevier Science, 1991).

9 See generally Hanemann, 81 Am Econ Rev 635.

10 See text accompanying notes 81-83. 
This Article focuses on the problems associated with the use of CV in environmental law. Like other valuation techniques, CV typically seeks to estimate the total value respondents place on a change in an environmental good. CV is an alternative to market information for goods that are not easily traded, such as natural parks or rivers, that surveys how much a representative sample population values such amenities. Respondents are usually asked either how much they are willing to pay ("WTP") to clean up or preserve a natural resource, or, alternatively, how much they are willing to accept ("WTA") to forgo their existing rights to the amenity. ${ }^{11}$ The survey results are then aggregated and statistically analyzed to produce a measurement of the resource's overall value. ${ }^{12}$

From the outset, and throughout extensive empirical research, CV practitioners have observed that WTA questions almost always elicit much higher valuations than do WTP queries. ${ }^{13}$ As will be discussed, WTA and WTP questions imply different property rights to the resource involved: WTA suggests that the public (respondent) owns the resource, while WTP suggests that they do not. Yet CV practitioners, in keeping with the conventional perspective that property rights should have little effect on value, have shown relatively little recognition of these implications. Instead, they often attribute WTA-WTP differences to survey error or respondent bias. But recent work has shown that the WTA-WTP divergence may demonstrate that for lesssubstitutable goods, including various public goods, value varies sharply as property rights change.

We argue that in dealing with less-substitutable goods, it is not possible to select the appropriate form of CV survey or interpret the resulting estimates without first undertaking a legal analysis of the rights to the good in question. This creates new problems for CV analysts, because specifying public rights in national land, air, and water amenities is becoming more complex. If, as appears likely, less-substitutable goods become increasingly significant in American jurisprudence, the realization

11 For a recent survey of the WTP and the WTA issues in CV analysis, see Mitchell and Carson, Using Surveys to Value Public Goods at 30-41 (cited in note 5). WTA is sometimes signified in CV literature as willingness to sell ("WTS").

12 For a detailed explanation of the statistical computations used to ensure the reliability of CV results, see id at $220-28$.

${ }_{13}$ See Ronald G. Cummings, et al, Valuing Environmental Goods: An Assessment of the Contingent Valuation Method 35-36 (Rowman \& Allanheld, 1986); Mitchell and Carson, Using Surveys to Value Public Goods at 30-38. 
of environmental and other national objectives may require a major reconsideration of the law and economics of property rights and valuation.

Part I of this Article describes how CV, once an obscure experimental technique, emerged as the method of choice to perform valuations of a group of increasingly important environmental goods. Part II argues that, contrary to early theories, the divergence between WTP and WTA survey results observed for some less-substitutable goods is consistent with standard economic theory. The value of less-substitutable goods, including some important publicly-held natural resources, will vary with the allocation of property rights. In Part III, we explain that public rights in national assets have become increasingly unclear. As a result, litigation to define such rights could soon dramatically increase the costs of-and delay-America's environmental protection efforts. Legislative intervention may be necessary to avoid this outcome. The Article concludes with some thoughts on how the resolution of natural resource valuation issues in environmental law may eventually influence American jurisprudence more generally.

\section{Contingent VAluation ApPlications in ENVIRONMENTAL LAW}

Contingent valuation surveys, first suggested in 1947, were applied to practical problems in the 1960 s. $^{14}$ Soon after its inception, several criticisms of CV arose. Economists questioned whether structured surveys could measure the value of goods as accurately as market prices could. ${ }^{15}$ Commentators also feared that either the form of the survey itself would distort observed consumer preferences, or that the respondents might provide false data for strategic reasons. ${ }^{16}$ In response, CV proponents tried to test the accuracy of the technique by comparing surveygenerated values to known market prices for specific goods. ${ }^{17}$

14 See note 5. While Ciriacy-Wantrup is credited with inventing the CV method, its first practical application came with economist Robert Davis's attempts to estimate the recreation benefits of woods in Maine. See Robert $\mathrm{K}$. Davis, Recreation Planning as an Economic Problem, 3 Nat Res J 239, 245 (1963).

15 See, for example, Paul A. Samuelson, The Pure Theory of Public Expenditure, 36 Rev Econ \& Stat 387 (1954).

${ }^{16}$ See the discussion and materials cited in Mitchell and Carson, Using Surveys to Value Public Goods at 153-70 (cited in note 5).

17 See, for example, Peter Bohm, Estimating Demand for Public Goods: An Experiment, 3 Eur Econ Rev 111 (1972); Richard C. Bishop and Thomas A. Heberlein, Does 
Additional work attempted to demonstrate that CV surveys could be fine-tuned to reduce the more obvious forms of respondent bias. ${ }^{18}$ Despite promising results, many of the major issues about the method remain unresolved even after three decades of basic research. ${ }^{19}$

CV might well have remained an experimental curiosity but for America's emerging environmental protection regime, which required dramatic changes in valuation methodology. ${ }^{20}$ The Clean Water Act ("CWA") in 1977,, and then later CERCLA ${ }^{22}$ and the Clean Air Act ("CAA"), ${ }^{23}$ required new methods of valuing natural resources for which economic markets did not exist. In spite of continuing controversy over its validity, ${ }^{24} \mathrm{CV}$ became one of the primary methods of valuation.

CV achieved its prominence for three reasons. First, unlike more standard valuation methods, CV seemed responsive to theo-

Contingent Valuation Work?, in Cummings, et al, Valuing Environmental Goods at 123 (cited in note 13); Richard C. Bishop, et al, Contingent Valuation of Environmental Assets: Comparisons with a Simulated Market, 23 Nat Res J 619 (1983); Mark Dickie, et al, Market Transactions and Hypothetical Demand Data: A Comparative Study, 82 J Am Stat Assn 69 (1987).

${ }_{18}$ See Mitchell and Carson, Using Surveys to Value Public Goods at 231-32 (cited in note 5).

19 Many CV practitioners regard the method as still in its developmental stage. See, for example, V. Kerry Smith, To Keep or Toss the Contingent Valuation Method, in Cummings, et al, Valuing Environmental Goods at 162, 176 (cited in note 13) ("[W]e can draw no conclusions on [the] accuracy [of CV] based on what we know from research to date."); Raymond J. Kopp, Forward, in Mitchell and Carson, Using Surveys to Value Public Goods at xvi ("The contingent valuation method is still in its infancy and research regarding appropriate application procedures and tests of reliability are under way."). The broader range of social-science researchers may view CV with even more skepticism.

${ }^{20}$ See Mitchell and Carson, Using Surveys to Value Public Goods at 13-14.

2133 USC \$§ 1251-1387 (1988). The CWA originated in the Federal Water Pollution Control Act of 1948, Pub L No 80-845, 62 Stat 1155 (1948). Congress amended that Act several times. The 1977 amendments provided the alternative title, Clean Water Act, which has largely superseded the original title. See Pub L No 95-217, § 1, 91 Stat 1566 (1977).

${ }^{22}$ Comprehensive Environmental Response, Compensation and Liability Act of 1980 , Pub L No 96-510, 94 Stat 2767 (1980), as amended by the Superfund Amendments and Reauthorization Act of 1986 ("SARA"), Pub L No 99-499, 100 Stat 1613 (1986), codified at 42 USC §\& 9601-57 (1988 \& Supp IV 1992).

${ }^{23} 42$ USC $\$ \$ 7401-7642$ (1988 \& Supp IV 1992). The original Clean Air Act, 69 Stat 322 (1955), was completely revised by Pub L No 95-96, 91 Stat 685 (1977).

${ }^{24}$ For a comprehensive treatment of methodological problems in the application of $\mathrm{CV}$, as exemplified by the problem of valuing Grand Canyon visibility rights, see Daniel S. Levy, et al, Conceptual and Statistical Issues in Contingent Valuation: Estimating the Value of Altered Visibility in the Grand Canyon, RAND MR-344-RC (Aug 1993 draft) (on file with U Chi L Rev) ("RAND Report"). For more general accounts of methodological problems, see Mitchell and Carson, Using Surveys to Value Public Goods at 9-14, 295-306; Cummings, et al, Valuing Environmental Goods at 111-236. 
retical concerns over natural resource valuation. Second, a battle over regulatory politics culminated in an endorsement of CV by the Department of the Interior. Finally, litigants began to employ CV strategically to create leverage in complex environmental litigation.

\section{A. Theories of Natural Resource Valuation and CV}

The CWA and CERCLA forced economists to revise standard thinking about valuation in legal contexts. To enforce national environmental goals, both Acts permitted government plaintiffs, for the first time, to recover damages for harm to natural resources caused by the discharge of hazardous materials. ${ }^{25}$ Defining potential damage liability under the Acts proved highly contentious: how much should a polluter pay for damage caused to an isolated and rarely-used beach, forest, or stream? Predictably, industry representatives (and the Reagan and Bush administrations) tried to limit natural resource damages under the CWA and CERCLA to only those elements of value that could be measured by functioning markets. ${ }^{26}$ Environmentalists argued for much more expansive valuation techniques which would include, and go beyond, market measures. ${ }^{27}$

25 The first widely applicable damage provisions for harm to natural resources were $\S \S 311(f)(4)$ and (f)(5) of the CWA, codified at 33 USC $\S 1321(f)(4)$ and (f)(5). CWA damages cover the release of hazardous substances or oil, including "any costs or expenses incurred by the Federal Government or any State government in the restoration or replacement of natural resources damaged or destroyed." 33 USC $\S 1321$ (f)(4). While the statute had apparently been intended to award damages at least equal to resource restoration costs, the Department of the Interior adopted regulations reflecting a more limited interpretation. See text accompanying notes 39-63.

The damage provision of CERCLA is 42 USC § 9607(f)(1). Under CERCLA, dischargers of hazardous substances may be held liable for "damages for injury to, destruction of, or loss of natural resources, including the reasonable cost of assessing such injury, destruction or loss resulting from such a release." 42 USC $\$$ 9607(a)(4)(C). SARA amended CERCLA to provide that "in any case in which any provision of $\S 311$ of the CWA [33 USC $\S 13211$. is determined to be in conflict with any provision of CERCLA, the provisions of CERCLA still apply." 42 USC § 9654(c). Thus, case law, regulations, or other authorities pertaining to natural resource damage recoveries under CERCLA also govern damage actions under $\$ 311$ of the CWA.

Under both the CWA and CERCLA, the federal government or any affected state may sue to recover these damages as a "trustee" of the public interest in the resource. 33 USC § 1321(f)(5) (CWA); 42 USC § 9607(f)(1) (CERCLA).

${ }^{26}$ See Frank B. Cross, Natural Resource Damage Valuation, 42 Vand L Rev 269, 280 97 (1989); Frederick R. Anderson, Natural Resource Damages, Superfund, and the Courts, 16 BC Envir Aff L Rev 405, 440-56 (1989). These provide excellent reviews of the methodological, theoretical, and ideological debates surrounding the development of natural resources valuation principles under the CWA and CERCLA.

27 See Cross, 42 Vand L Rev at 285-97. 
The valuation debate centered on the fact that many natural resources are not readily, if ever, traded on functioning markets. To some economists, market-determined prices are the only reliable, legally significant measures of value. ${ }^{28}$ To them, if a good is traded and sold, it has measurable worth; to the extent it is not so traded, it has no measured value. In this view, the value of a natural resource is the sum of the value of all of its associated marketable commodities, such as timber, minerals, animals, and recreational use fees. Thus, harm to a heavily used, commercially exploitable national forest would generate significant damage liability, while pollution of isolated, unproductive environments, no matter how rare or beautiful, would not. ${ }^{29}$

Although reliance on market valuation to obtain a reliable estimate of some types of damages is methodologically consistent with mainstream economics, many balked at the possibility that the exclusive reliance on market methods would not measure the harm to national natural treasures unless the resources were traded on economic markets. ${ }^{30}$ They argued that even rarely used, noncommercial resources, such as scenic vistas or Alaskan beaches, possess significant, tangible value to the American public.

In response to these concerns, certain researchers developed new categories for elements of natural resource value that conventional damage theories could not easily accommodate. ${ }^{31}$ The concept of "use value" was created to designate pure market mea-

${ }^{28}$ See id at 281-85; Mitchell and Carson, Using Surveys to Value Public Goods at 5967 (cited in note 5).

${ }_{29}$ For example, consider two islands. One is readily accessible, heavily forested with high-quality redwood groves, and surrounded by oceans teeming with swordfish and salmon. The other is hard to visit and supports little timber and few commercial fisheries. Under conventional market-based economic analysis, damages for a massive oil spill followed by a fire that destroyed the vegetation, beaches, and fish of both of these islands would equal the sum of the exploitable resources lost by the first island, while the second island would have no legally significant damages.

In the influential decision Ohio $v$ United States Department of the Interior, $880 \mathrm{~F} 2 \mathrm{~d}$ 432, 445 (DC Cir 1989), the court discussed the inadequacy of pure market measures: "Interior could not possibly maintain that recovering $\$ 15$ per pelt for fur seals killed by hazardous substance release would enable the purchase of an 'equivalent' number of fur seals." For further discussion of this case, see text accompanying notes 49-63.

so See Cross, 42 Vand L Rev at 271-72.

31 For a summary of the debate over basic theoretical and practical issues behind the different categories of natural resource value, see id at 280-97; Mitchell and Carson, Using Surveys to Value Public Goods at 55-67. Economists have not used new natural resource valuation terminology consistently. For example, concepts of option value or existence value are often subject to considerable nuance, and some economists use the same terms in contradictory ways. See Cross, 42 Vand L Rev at $281 \mathrm{n} 53$. 
sures, such as natural resource commodity prices or recreational fee revenues. ${ }^{32}$ A second category, "existence value" was invented to represent the extent that people enjoy benefits from, and would be willing to pay for, the knowledge that remote, pristine environments such as Alaskan wildlife refuges or deep-sea volcanic reefs simply exist. ${ }^{33}$ There are three subcategories of existence value: (1) "option value," which represents the amount that people would be willing to pay to ensure an amenity's survival so that they might have the chance to enjoy it in the future-a family in Florida, for example, might derive utility from the knowledge that a continent away, Yosemite was being maintained for their potential future use; (2) "vicarious value," measuring the appreciation of others' use of the resource; and (3) "intertemporal value," measuring anticipation of the use of the resource by future generations..$^{34}$ Finally, the notion of "intrinsic value" was developed to represent the inherent value of natural resources, considered independently of human existence or use. $^{35}$ Discussions of this last category often take on a metaphysical tone, with commentators citing religious and philosophical works to describe it. $^{36}$

As this new typology of natural resource valuation gained credibility, CV attracted attention because it, alone among several alternative techniques, appeared to measure existence values (especially option values) as well as use values. ${ }^{37}$ Unlike market

32 See Cross, 42 Vand L Rev at 281-85.

${ }^{33}$ Id at 285-92.

3 Id.

${ }^{35}$ Id at 292-97.

${ }^{36}$ See, for example, id (citing St. Francis of Assisi and Jeremy Bentham).

${ }^{37} \mathrm{CV}$ specialists, reviewing recent court decisions affirming the use of $\mathrm{CV}$ for environmental evaluations, concluded that "[s]ince contingent valuation techniques are the only way known to measure [ ] nonuse damages, they will play a key role in determining the magnitude of awards in certain cases." Raymond J. Kopp, et al, Natural Resource Damages: The Economics Have Shifted After Ohio v. United States Department of the Interior, 20 Envir L Rptr 10127, 10130 (1990).

Alternative techniques for valuing natural resources include direct consumer behavior measures, such as the amount people pay to use the resources in question, and hedonic price valuation, which assesses the impact of a natural resource on a marketed resource. Direct measures, which in effect aggregate the costs associated with accessing a natural resource, including "travel expenses, entrance fees, the opportunity cost of travel time invested, and similar travel-related costs," suffer from numerous conceptual problems. See Anderson, 16 BC Envir Aff L Rev at 444 (cited in note 26). Such measures are reasonable indicators of overall resource value only if access costs are significant relative to the total value of the resource, a questionable assumption. Further, it is extremely difficult to value travel time and opportunity costs, as the method requires. Id.

Hedonic price valuation faces other difficulties. A typical use of this method would compare the price of similar homes in polluted and non-polluted areas to isolate the 
or related measurement techniques, CV surveys can directly ask respondents how much they would pay to obtain, or accept to sell, their right to each of these aspects of the value of the resource. In theory, surveys can be worded so that the answers reflect the sum of the respondents' use, existence, and intrinsic values. ${ }^{38}$ Consequently, as the frequency of environmental damage disputes rose, the practical application of CV surveys also increased.

\section{B. Regulatory Politics and the Judicial Validation of CV}

Regulatory conflicts, particularly the bitter litigation over regulations implementing the damage provisions of the CWA and CERCLA, promoted the use of CV. The Acts directed the President, who delegated the job to the Department of the Interior ("DOI"), to formulate damage valuation rules by December, $1982 .{ }^{39}$ The Acts required two types of rules. For special sites, "Type A" rules set out "standard procedures for simplified assessments requiring minimal field observations." ${ }^{30}$ In practice, Type A rules are used only for oil spills in aquatic environments. ${ }^{41}$ For all other locations, primarily major spills requiring site-specific damage valuation, "T2 "Type B" rules provide "alternative protocols for conducting assessments in individual cases to determine ... short- and long-term injury, destruction, or loss." ${ }^{\prime 3}$ The Acts authorize the executive branch to identify the best available procedures to determine both types of damages. ${ }^{44}$ Political controversy has centered on Type B procedures, because they affect the vast majority of cases.

The DOI pursued its rulemaking function lethargically. The agency did not adopt Type B rules until 1986, four years after the initial deadline. ${ }^{45}$ Soon thereafter, Congress enacted the

effects of pollution on value. When a natural resource is involved, it is difficult to find a marketable commodity that will reflect its value. For example, the price of a house located near the Grand Canyon might decline as a result of certain types of environmental damage, but it would be difficult to separate the effect of, say, changes in visibility quality from the effects of other factors.

${ }^{38}$ See, for example, Cross, 42 Vand L Rev at 315-20 (cited in note 26).

${ }^{39}$ See 42 USC § 9651(c)(1); Exec Order No 12316 § 8(c)(3).

4042 USC \$ $9651(\mathrm{c})(2)$.

41 See Cross, 42 Vand L Rev at 321 n 273.

42 Id at 321-22.

4342 USC $\$ 9651(c)(2)$.

44 Id.

45 Final rules were adopted in August, 1986. Natural Resource Damage Assessments, Final Rule, 51 Fed Reg 27,720 (1986), codified at 43 CFR §§ 11.10-11.93 (1992). The initial 
Superfund Amendments and Reauthorization Act ("SARA"), amending CERCLA and the damage provisions of the CWA simultaneously. ${ }^{46}$ SARA gave the DOI six months to revise its damage assessment regulations to conform with the amendments. ${ }^{47}$ Two years later, the DOI published and adopted revised Type B rules, which were challenged in court by state governments, environmentalists, and industry groups. ${ }^{48}$

After years of procedural and substantive wrangling, the D.C. Circuit finally settled the regulations dispute in Ohio $v$ United States Department of the Interior, which clarified the theory of natural-resource value embodied in the DOI rules. ${ }^{49}$ As adopted, the Type B rules had provided that damages for harm to natural resources would be measured by "the lesser of [ ] restoration or replacement costs or diminution of use values. ${ }^{, 50}$ Environmentalists objected that this formulation would greatly undervalue damage to natural resources because use measures would almost always be less than the cost of completely restoring a natural amenity. ${ }^{51}$ They argued that, in effect, the rules simply excised non-market measures such as option or existence values from the damage assessment formula.

The DOI rules also created a hierarchy of valuation methods. ${ }^{52}$ Plaintiffs suing for natural resource damages could use CV surveys only if use values or other market methodologies

deadline was December 11, 1982. 42 USC $\S 9651$ (c)(1). For a brief history of the process of DOI rulemaking with regard to the damage provisions of the CWA and CERCLA, see Ohio, 880 F2d at 440 .

${ }^{46}$ See note 25. See also Ohio, 880 F2d at $439-40$ (describing the effects of SARA on CERCLA damage provisions).

47 See 42 USC \$ 9651(c)(1).

48 The DOI issued revised regulations in February 1988. 53 Fed Reg 5,166 (1988). See Ohio, $880 \mathrm{~F} 2 \mathrm{~d}$ at 440 . Similar groups had also challenged the pre-amendment rules. Id.

49880 F2d 432 (DC Cir 1989). The major issue in Ohio was whether pure-use value measures or measures reflecting resource restoration costs best reflected congressional intent in CWA and CERCLA damages. See id at 459. But the litigation over the valuation regulations also involved other complex, highly technical matters. Among the issues ultimately decided by the D.C. Circuit were whether the DOI's requirement that damage assessors consider only the resource's "committed uses" was consistent with congressional intent, id at 461-62; whether the DOI's decision to use a $10 \%$ discount rate to calculate the net present value of future injury costs was appropriate, id at 464-65; whether permitting potential defendants in a CERCLA action to conduct preliminary damage assessments was improperly preferential, id at 465-68; whether the DOI's limitations of potential assessment recoveries were proper, id at 468; and whether the DOI's regulations adopted an overly-stringent test for damage causation, id at 468-473.

so 43 CFR § 11.35(b)(2) (1992).

51 Ohio, 880 F2d at $441-42$.

${ }^{52}$ See 43 CFR $\S \S 11.83(c)-(d)$. See also Ohio, 880 F2d at $462-64$. 
could not reasonably be applied to their cases. ${ }^{53}$ Meanwhile, industry interests, while generally pleased with the DOI's "lesser of' rule, strenuously resisted any legitimation of CV because of the huge potential damage measures CV surveys were known to generate. ${ }^{54}$ They challenged the inclusion of $\mathrm{CV}$ in the regulations on the grounds that the method was speculative and inferior to other available valuation procedures. ${ }^{55}$

In Ohio, the court adopted the environmentalists' position that natural resource damage measures must include more than use valuation to be consistent with Congressional intent. ${ }^{56}$ The court struck down the DOI's "lesser of" rule, on the grounds that, in practice, it would limit natural resource damages to values measurable in functioning markets. ${ }^{57}$ Instead, the court took the position that the real value of natural resources extends beyond the sum of their marketable commodities. ${ }^{58}$ Looking to the language of CERCLA and the CWA, which mandated recoveries to compensate for the full effects of environmental harm, the court found the DOI's rules inconsistent with Congressional intent because the rule would undervalue resources. ${ }^{59}$ The Court therefore instructed the DOI to revise the Type B rules to develop damage assessment methodologies that measured more than merely use values. ${ }^{60}$

The court also rejected the industrialists' challenge to the inclusion of $\mathrm{CV}$ in the DOI regulations. ${ }^{61}$ It dismissed their arguments that $\mathrm{CV}$ was unreliable or generated inflated damage measures as striking "at CERCLA, not CV's implementation," and therefore appropriately considered "only by Congress." 62 To

${ }^{53}$ See 43 CFR § 11.83(d).

${ }^{54}$ See Ohio, $880 \mathrm{~F} 2 \mathrm{~d}$ at 476.

ss Id at 476-78. For example, industry petitioners contended that CV was unreliable because it generated such remarkably high estimates of resource value. As evidence, they cited a study that estimated the option and existence value of whooping cranes in Texas at $\$ 109$ million (or approximately seven dollars for each resident of the state), a result they derided as unjustifiably high. Id at $477 \mathrm{n} 86$.

${ }_{56}$ Id at 462-64.

57 Id at 455-59.

5s Id at $462-64$.

59 Id at 450 .

60 Id at 481 .

61 Id at 478 . The DOI's regulations defined CV as "all techniques that set up hypothetical markets to elicit an individual's economic valuation of a natural resource." 43 CFR $\$ 11.83(d)(5)(i)$. The court discussed at length the theory and practice of $C V$, noting that it was the only method recognized by practitioners as being reasonably effective in eliciting existence and option values. $880 \mathrm{~F} 2 \mathrm{~d}$ at $475-76$.

62 Ohio, 880 F2d at 477. 
the extent that Congress required environmental polluters to pay the full costs of the harm they cause, the court found CV surveys to be perfectly consistent with the intent of the CWA and CERCLA, because in theory CV measures such costs more completely than do other methods. ${ }^{63}$ Consequently, the court upheld the DOI's inclusion of $\mathrm{CV}$ as a method for assessing Type B damages.

\section{Environmental Litigation Strategy and CV}

A final cause of the rapid growth of $\mathrm{CV}$ in environmental law is the use of CV surveys to obtain strategic advantages in environmental litigation, even where damages are not explicitly at issue. Plaintiffs and defendants alike use CV surveys more and more frequently to provide best- or worst-case assessments of the costs of regulatory compliance or possible settlements. Low CV results provide an argument against expensive retrofit programs or investments in pollution-reducing technology. Meanwhile, both private and government plaintiffs in environmental actions use high-damage $\mathrm{CV}$ estimates to compel settlements with recalcitrant defendants.

For example, while the CAA requires that the "best available retrofit technology" be employed to reduce air pollution in certain locations, it has no damage provisions; the act is simply remedi$\mathrm{al}^{64}$ But when the costs of compliance are quite high, as in the case of efforts to reduce airborne pollutants from power plants near the Grand Canyon, affected parties have resorted to CV analyses in an attempt to limit the extent of the remedial investments they must make. ${ }^{65}$ If investments to clean up Grand Can-

63 Id.

64 The CAA requires that major stationary sources existing on or after August 7, 1977, and that have been in operation less than 15 years, must use the best available retrofit technology to mitigate air pollution if they contribute, or can reasonably be anticipated to contribute, to any impairment of visibility in certain designated class 1 areas, which include national parks and any other unique natural resources. CAA $\$$ 169A(b)(2)(A), codified at 42 USC $\$ 7491(\mathrm{~b})(2)(\mathrm{A})$. Apart from this remedial function, the $\mathrm{CAA}$ is unique among the major environmental statutes in that it expressly awards no damages for harm to air quality. See generally David P. Currie, Air Pollution: Federal Law \& Analysis § 8.14 (Callaghan, 1981 \& Supp 1991).

65 In 1991, the Environmental Protection Agency invited public comment on the issue of whether the Agency should require the Navajo Generating Station to use the best available retrofit technology to reduce its emissions, which have been shown to impair wintertime visibility in the Grand Canyon. The Canyon is a class 1 area under $\S 162(a)$ of the CAA, 42 USC \& 7472(a). See United States Environmental Protection Agency, Approval and Promulgation of Implementation Plans: Revision of the Visibility Federal Implementation Plan for Arizona, 56 Fed Reg 5173-90 (1991) (proposing amendments to 40 
yon air would cost $\$ 500$ million, and CV studies indicate that the public values pristine Grand Canyon air at only $\$ 200$ million, polluters will offer the CV analysis to define an upper limit for CAA compliance.

At the same time, plaintiffs can use CV studies to compel rapid compliance and settlement in remedial environmental disputes triggered by major oil spills or other disasters. ${ }^{66}$ Because of the enormous costs of simply cleaning up these harms, environmental offenders might well choose to litigate rather than settle at the outset of an action. CV analyses suggesting substantial ultimate liability can give plaintiffs the leverage needed to induce recalcitrant parties to settle, making immediate payments available to mitigate damage.

Theoretical, regulatory, and strategic developments therefore virtually guarantee that litigants will continue to introduce $\mathrm{CV}$ surveys into environmental disputes in the future. Indeed, CV practitioners have already become standard players on most major environmental litigation teams. Still, questions persist concerning the relationship of property rights to measures of natural resource value. Until these issues are resolved, CV results may be misleading at best, and at worst entirely contrary to the legislative intent behind federal environmental statutes.

\section{PROPERTY RIGHTS AND ECONOMIC VALUES: WHY WTP AND WTA RESULTS DIFFER}

One of the most significant problems with using $\mathrm{CV}$ to value natural resources is the dramatic divergence between survey results based on WTP ("willing to pay") and WTA ("willing to accept") questions. Researchers have repeatedly demonstrated that WTA questions generate values from three to nineteen times

CFR § 52 (AD-FRL-3700-4)). At issue was the extent to which the EPA should require the station to invest in pollution-reducing technology, given that estimates of the value of clean air in the Grand Canyon vary. For a summary and critique of the $\mathrm{CV}$ studies presented, see RAND Report (cited in note 24 ).

${ }^{66}$ It is difficult to obtain precise information regarding the use of $\mathrm{CV}$ in large-scale environmental disaster cases, such as the Exxon Valdez and Sacramento River spills, because the litigants frequently insist that the studies remain sealed during and even after the course of litigation. However, journalistic accounts and the publication of related research suggest that both plaintiffs and defendants employ CV surveys in such actions to generate leverage in settlement negotiations. See, for example, Carla Marinucci, Putting a Price on Pollution: Environmental Economists Figure the Cost of Clean Air, Clean Water, San Fran Examiner E1 (Aug 4, 1991); Jerry A. Hausman, ed, Contingent Valuation: A Critical Assessment (Elsevier Science, 1993). 
greater than those elicited by WTP queries. ${ }^{67}$ Each form of question clearly implies different property rights. In a WTA format, the respondents are asked to specify the price for which they will sell their existing rights to an amenity, allowing some form of degradation of the good, or foregoing some improvement. WTA surveys thus assume that respondents already own implicit rights to the amenity at issue. ${ }^{68} \mathrm{WTP}$, in contrast, supposes that the respondents do not yet have the right to enjoy an amenity in a certain condition; instead, people are asked the most they would pay to obtain a right to have the amenity improved or to prevent its degradation. WTP questions presume that individuals other than the respondents have the right to the resource in question. ${ }^{69}$ However, CV practitioners generally have not accepted that the WTA-WTP difference results from the different legal contexts implied by their choice of survey questions. ${ }^{70}$ Instead, consistent with conventional law and, until recently, economic theory, they simply treated the WTP-WTA divergence as error. ${ }^{71}$ In the end, WTA has been generally discarded in favor of the seemingly more reliable WTP methodology. ${ }^{72}$

Dismissing the WTA-WTP problem in this fashion, we argue, is wrong for a group of goods that may be considered unique or "less-substitutable." WTA and WTP estimates of the value of unique goods should vary significantly, because WTA and WTP imply different property rights. In fact, CV practitioners cannot

67 See note 6.

68 See generally Mitchell and Carson, Using Surveys to Value Public Goods at 30 (cited in note 5). Mitchell and Carson review the literature concerning WTP and WTA divergence and the attempts to explain this result without reference to differential property rights. Id at 34-38. They are also noteworthy for their attempt to address the property rights issue and to justify the use of WTP on the basis of "a new property rights approach." See discussion in Section III.C. and Carson, Constructed Markets at 130 (cited in note 8).

69 See Hanemann, 81 Am Econ Rev at 635-47 (cited in note 8); NOAA Report at 31 (cited in note 6).

70 NOAA Report at 31.

${ }^{71}$ See Herbert Hovenkamp, Legal Policy and the Endowment Effect, $20 \mathrm{~J}$ Legal Stud 225, 225-29 (1991). Hovenkamp explains that the WTA-WTP difference is traditionally explained as an income effect of the respondent's change in property rights. Since money added to income has diminishing marginal utility, the respondent would not be willing to accept less for the right than she would be willing to pay. This theory, however, may not account for the magnitude of the difference between WTA and WTP survey values. Id at 226.

${ }_{72}$ See Peter A. Diamond and Jerry A. Hausman, On Contingent Valuation Measurement of Nonuse Values, in Jerry A. Hausman, ed, Contingent Valuation: A Critical Assessment 3-38 (Elsevier Science, 1993) (stating that the "persistent difference" between WTA and WTP results "casts doubt on the entire enterprise"). 
properly analyze the value of goods, including many natural resources, until the underlying property rights applicable to the amenity involved are specified. Depending on who "owns" the natural resources at issue, either WTA or WTP questions reflect the conceptually appropriate legal and economic CV questions to value a less-substitutable good. And given the magnitude of the WTA-WTP divergence, the failure to employ the appropriate CV question may impart a severe bias to the valuation of the good. ${ }^{73}$

Economists initially proposed several explanations for the large difference between WTA and WTP responses, believing that standard economic theory provided little justification for the results. ${ }^{74}$ Some argued that WTA was just more difficult for respondents to consider than WTP: as respondents gained experience in CV procedures, WTA results would converge on WTP. ${ }^{75}$ But attempts to demonstrate this proposition empirically have been unsatisfying. Even in repeated-bid experiments in which respondents engaged in several successive surveys, statistically significant variance between WTA and WTP responses could not be eliminated. ${ }^{76}$

Psychological theories may also help to explain the divergence between responses to WTP and WTA questions. For example, "prospect theory" postulates that individuals simply dislike losses more than they like gains of equal magnitude. ${ }^{77} \mathrm{CV}$ respondents therefore require more compensation to avoid the amenity loss implied by typical WTA questions than to purchase the same amenity as WTP queries usually suppose.

${ }^{73}$ For an argument that the allocation of rights reflected by WTA or WTP perspectives crucially affects public welfare decisions and social efficiency outcomes, see Hovenkamp, $20 \mathrm{~J}$ Legal Stud 225 (cited in note 71).

74 See Alan Randall and John R. Stoll, Consumer's Surplus in Commodity Space, 70 Am Econ Rev 449 (1980). For a discussion of four different attempts to explain the WTPWTA divergence, see Mitchell and Carson, Using Surveys to Value Public Goods at 34-38 (cited in note 5).

${ }_{75}$ See, for example, Don L. Coursey, et al, The Disparity Between Willingness to Accept and Willingness to Pay Measures of Value, 102 Q J Econ 679 (1987). Coursey and his co-authors investigated the difference between WTP and WTA in a repeated bid experiment and claimed to find that, after a series of repeated closed-bid auctions, respondents' WTA and WTP converged. Although WTP did increase slightly, most of the change was observed in WTA, which declined by about half. Id at 688 .

${ }^{76}$ See Robin Gregory and Lita Furby, Auctions, Experiments and Contingent Valuation, 55 Public Choice 273, 280-85 (1987) (analyzing the data from the Coursey experiment and finding that WTA and WTP valuations were statistically different even in the last rounds of bids).

${ }_{77}$ The leading work is Daniel Kahneman and Amos Tversky, Prospect Theory: An Analysis of Decision Under Risk, 47 Econometrica 263 (1979). 
Although prospect theory suggests a mechanism that may help us understand why WTP responses differ so greatly from WTA responses, the losses and gains which are so critical to prospect theory do not coincide uniquely with the WTP and WTA question forms. ${ }^{78}$ Prospect theory's explanation for the divergence between WTA and WTP assumes that the WTA question reflects a loss while WTP reflects a gain. Any WTA (or WTP) question, however, can be rephrased as a WTP (or WTA) query.

For example, a standard WTA survey might ask respondents how much they would have to be paid to give up their current rights to clean air. The same situation can also be expressed as a WTP question: respondents could instead be asked how much they would pay to avoid a loss of the air quality they currently enjoy. Since each form of the question implies the same degree of loss, under prospect theory, the respondents' answers should be similar in magnitude. Irrespective of WTP or WTA language, answers to questions that involve losses should tend to converge, as should all of those implying only gains. While a careful coding of existing WTA-WTP survey results into loss or gain categories has yet to be performed, the obvious trend of the available evidence is that CV surveys are in fact highly sensitive to the form of WTP and WTA questions. ${ }^{79}$ This indicates that something other than (or at least in addition to) the fear of loss explains the observed valuation response divergence.

Although both prospect theory and recent developments in economics ${ }^{80}$ partially explain the WTA-WTP divergence, without a definition of property rights neither approach provides a principled rationale for selecting one form of question over another. The determination of the conceptually appropriate form of CV query is a matter of property rights, not economics or psychology.

Recent work shows that when goods do not have close substitutes, and when the income elasticity of demand for the good is large, WTA and WTP should differ greatly in accordance with the property rights implied by each question. ${ }^{81}$ The large divergence

${ }^{78}$ For a discussion of the various hypotheses that must be derived and tested to assess the accuracy of prospect theory on which the following section relies, see RAND Report at 9-14 (cited in note 24).

79 See note 6.

so See generally Hanemann, 81 Am Econ Rev 635 (cited in note 8).

81 The following discussion draws heavily on the work of Hanemann, $81 \mathrm{Am}$ Econ Rev 635. Hanemann explicitly derives the economic relationships determining the divergence between WTA and WTP. He demonstrates that, in addition to the elasticity of substitution, see note 82 , between a specific amenity and all other goods that respondents might consume, the income elasticity of the direct ordinary demand function for the amenity and 
between empirical estimates of WTA and WTP is therefore not in fact inconsistent with standard economic theory, as previously believed.

To demonstrate how a good's substitutability and income elasticity determine whether property rights affect value, consider a simple example of WTP and WTA analysis based on actual CV studies of visibility in the Grand Canyon. Figure 1 plots individuals' hypothetical utility curves for visibility in the Grand Canyon ("VGC") and for all other goods ("AOG"). In the example, there are two possible levels of visibility in the Grand Canyon, represented by $q^{1}$ and $q^{0}$, with $q^{1}>q^{0}$ (that is, $q^{1}$ represents cleaner air than $\mathrm{q}^{\circ}$ ). "I" represents a given level of income in terms of all other goods consumed by the respondents. $U^{1}$ and $U^{0}$ represent two utility levels, with $U^{1}>U^{0}$. Given income $I$ and a level of visibility equal to $\mathrm{q}^{0}$, individuals will enjoy the level of utility represented at point $A$ on utility curve $U^{0}$. Given income I and a higher level of visibility, $\mathrm{q}^{1}$, individuals would achieve greater utility as represented by point $\mathrm{B}$ on utility curve $\mathrm{U}^{1}$.

In Figure 1, WTP is the amount of AOG that individuals would be willing to pay in exchange for an improvement in VGC without altering their utility levels. For example, utility-maximizing individuals would be equally happy at points $\mathrm{C}$ and $\mathrm{A}$. They would be willing to reduce their income from $I$ to $\mathrm{I}^{\mathrm{c}}$ in exchange for an increase in visibility from $q^{0}$ to $q^{1}$. The difference, $\mathrm{I}-\mathrm{I}^{\mathrm{c}}$, is therefore the value of utility-maximizing individuals' WTP.

WTA is the additional amount individuals would have to receive in exchange for a reduction in VGC without altering their utility levels. In Figure 1, utility-maximizing individuals would be equally happy at points $\mathrm{D}$ and $\mathrm{B}$. They would be willing to reduce the VGC they enjoy from $q^{1}$ to $q^{0}$ in exchange for an increase in AOG from $I$ to $I^{D}$. The difference, $I^{D}-I$, is equal to utility-maximizing individuals' WTA.

income effects will influence WTA and WTP results. While Hanemann's work explains the divergence between WTA and WTP in a manner consistent with economics, it does not constitute empirical evidence that economic factors alone explain the observed phenomenon. Pending explicit empirical tests, it remains possible that other causes, such as those described by prospect theory, see text accompanying notes 77-79, explain the results.

It is also important to note that Hanemann's work is not inconsistent with the Coase Theorem. See text accompanying notes 1-3. The Coase Theorem applies only under specific assumed conditions concerning the nature of substitutability, transaction costs, and other economic factors. Hanemann's analysis merely suggests that when goods are unique, or have fewer close substitutes than the Coase Theorem assumes, a different relationship between property rights and economic valuation applies. 


\section{Figure 1}

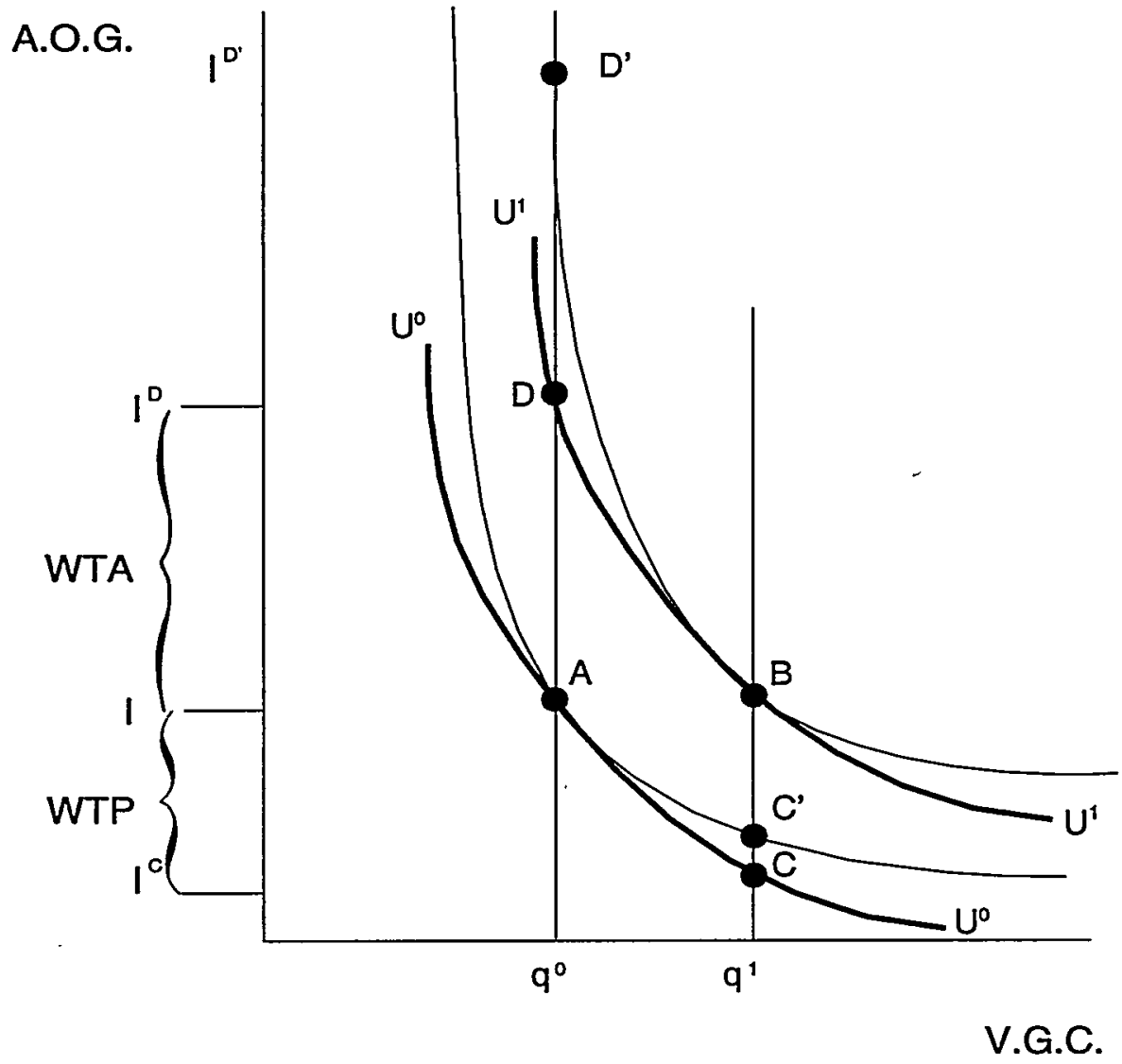

As Figure 1 demonstrates, the divergence between WTA and WTP is, in part, a function of the shape of the utility curves, which represents the substitutability of VGC for AOG. The greater the curvature, the less substitutability exists between VGC and AOG: the elasticity of substitution between VGC and AOG dwindles. ${ }^{82}$ For example, as $U^{1}$ becomes steeper above point $B$, it will intersect with the vertical line $q^{0}$ at some point above $D$,

82 Elasticity of substitution measures the responsiveness of consumption of one good to a change in the price of another good. A large elasticity of substitution between two goods means that even relatively small changes in the price of one good will result in large changes in the consumption of the other. 
such as $D^{\prime}$. At this point, WTA will increase to equal $\mathrm{I}^{\mathrm{D}}-\mathrm{I}$. Alternatively, as $U^{0}$ becomes flatter below point $A$, it will intersect the vertical line $q^{1}$ at a higher point, such as $C^{\prime}$, reducing WTP.

In the extreme case of no substitutability between VGC and AOG, the utility curves would be right angles: the elasticity of substitution between VGC and AOG is said to be zero. In this case it would not be possible to compensate individuals for a reduction in visibility from $\mathrm{q}^{1}$ to $\mathrm{q}^{0}$, because WTA would be infinite. At the same time, an increase in visibility from $q^{0}$ to $q^{1}$ would be virtually worthless, because WTP would approach zero. At the other extreme, perfect substitutability, the utility curves would be straight lines. At each point, individuals would be perfectly indifferent to VGC or AOG exchanges; the elasticity of substitution is said to be infinite. But as the assumption of perfect substitutability is relaxed, curvature will reemerge, once again generating WTA-WTP differentials. Large differences in WTA and WTP should occur for goods that do not have close substitutes. $^{83}$

The divergence between WTA and WTP also depends upon the income elasticity of demand for VGC. In simple terms, a positive income elasticity of VGC means that as an individual's income increases, he will want to "consume" greater visibility in the Grand Canyon. Similar increases in consumption associated with an increase in income are observed for most goods. Some have argued the income elasticity for certain environmental goods may be close to zero. For certain environmental goods it seems plausible that the income elasticity of demand is small-cleaner Alaskan coastlines may have little or no value to many people in the lower 48 states. After all, it is possible that very few people from the lower 48 would travel to some obscure, barren Alaskan coast, regardless of their wealth.

In contrast, however, millions of people travel to view the Grand Canyon. For such highly visited resources, it would be hard to deny the high value the public places on the good. The likelihood of some positive and appreciable income elasticity of demand for visibility in the Canyon seems great. It seems probable that many would consider visibility in the Grand Canyon to have no close substitutes and that the income elasticity of VGC is appreciable. Under these conditions, a sizeable divergence between WTA and WTP can be expected.

83 Note that as the elasticity of substitution approaches zero, the divergence between. WTP and WTA should be large even when income effects are small. 
This result makes intuitive sense. It is to be expected that people will tend to value more highly those items or amenities, such as their home, limbs, or unique natural resources, that they have some present right to enjoy and for which ready substitutes do not exist. One would expect them to demand a large payoff to give up their rights to enjoy these amenities. In contrast, people can be expected to find less value in more-substitutable goods, or goods that in some sense are more easily relaced. In many conventional law-and-economic analyses, one individual unit of a good is considered freely substitutable because people attach no special significance to it; one bushel of wheat is the same as all others. But, apart from the most mundane daily commodities, individuals unquestionably do develop special attachments to many of the amenities they enjoy. Such goods are not freely substitutable, and their owners will demand a premium to sell their present rights to enjoy them.

We contend that WTA and WTP divergence reflects, in part, this valuation process. Many goods may have some component of substitutability. For most goods, in fact, the unique or item-specific value of the good is a minor or even non-existent portion of its value. But for some goods, the item-specific value of the good contains most or even all of its value. There is thus a spectrum of unique or item-specific value for goods in general.

For example, some individuals may place an item-specific value on their car. For most individuals, however, the item-specific value is a small part of the car's value. Our legal system often ignores this item-specific portion of the value, as, for example, in awarding damages in contract and tort. Determining the item-specific value would be too costly in most cases, and typically would hardly alter the assessed value of the car. For other goods, the item-specific value of the good may represent virtually all of its value. For these goods the divergence between WTA and WTP may be large, and may represent an important component of the real value of the good. For this group of goods, which includes some goods of the type that will be valued with $C V$, the choice of WTP or WTA may be very important.

Many CV practitioners have employed the WTP form regardless of the conceptually appropriate form of the question, justifying their choice in part with the belief that there was no theoretical explanation for the observed empirical difference between the two forms. ${ }^{84}$ But if economic analysis explains why WTA and

See notes 67-72 and accompanying text. 
WTP responses should differ, this frequently invoked justification is no longer valid. The proper form of the CV question would then depend on our understanding of the proper allocation of initial property rights to the good.

Some CV practitioners, however, may still opt for the use of WTP queries even where the WTA form is conceptually more appropriate, believing that the bias introduced by the WTP form will be small in comparison to other inaccuracies introduced by the WTA form. These inaccuracies include unrealistically high average valuations and suspiciously wide variations in responses among others. ${ }^{85}$ This may be the case; however, this belief does not eliminate the very large potential bias that may be introduced when the conceptually inappropriate form is used.

If WTA and WTP responses differ because of the economic mechanisms discussed above, then the form of the CV survey matters crucially. And in any given case, a conceptually appropriate CV survey cannot be designed until the property rights to the amenity in question have been defined. To return to the example described in Figure 1, if the public owns the legally significant rights to clean air in the Grand Canyon, then only WTA questions are conceptually appropriate. If potential polluters have the present right to degrade Grand Canyon visibility, then only WTP questions reflect the property rights defined by the law. In cases where WTA questions reflect the property rights at issue, WTP surveys may dramatically undervalue natural resources; where WTP applies, WTA surveys may overvalue natural resources. ${ }^{86}$

The choice of the conceptually appropriate form of the question, WTP or WTA, thus boils down to a task of defining property rights. Goods valued with $\mathrm{CV}$ often do not have close substiutes, and in that case cannot be valued apprpriately through this methodology until the underlying legal rights to the amenity have been determined. For natural resources like visibility in the Grand Canyon, defining property rights may seem fortuitously simple. Many commentators, and even the DOI itself, have taken for granted that the public is the "owner" of natural resources. ${ }^{87}$

${ }^{85}$ See, for example, Cummings, et al, Valuing Environmental Goods at 37-70 (cited in note 13).

${ }^{86}$ For a general discussion of the potential under- and over-valuation problems involved in WTP and WTA surveys, see Cross, 42 Vand L Rev at 335-39 (cited in note 26).

${ }_{87}$ For example, the NOAA Report concludes:

When the service of a resource is diminished, asking the user what he should be paid to accept the reduction seems more appropriate. The concept of [a] public good is that the good belongs to no one person but rather the public at large. As the public's rep- 
If so, the current near-exclusive use of WTP in environmental law disputes is inappropriate; when the public own the good, WTA analysis alone is conceptually appropriate. It is far too facile, however, to assume that the public owns the legally significant rights to natural amenities. Instead, public and private rights in natural resources grow increasingly complex.

\section{New Challenges to Natural Resource Property RIGHTS}

The economics of less-substitutable goods suggests that property rights must be defined before the valuation of natural resources can be accomplished in a principled way. Accomplishing this task, however, is more difficult than it appears at first. The intuitive belief that the public "owns" natural resources is largely derived from federal common law, which views the public's interests in government land as precisely analogous to the rights private landholders enjoy in their property. ${ }^{88}$ If this principle were

resentative, the trustee should be considered the rightful owner of the resource and be awarded a compensation equivalent to the willingness to [accept] on the part of the public.

NOAA Report at 31 (cited in note 6). Cross concludes:

[Another] reason for selecting [WTA] derives from the context of natural resource damages. Government seeks to recover damages to resources that the public already owns. It makes more sense intuitively to view the natural resources as "sold" to the damaging party, rather than to require the public to "pay" for resources that already belong to it. The willingness to pay approach is more relevant to enhancing wildlife opportunities beyond those already extant.

Cross, 42 Vand L Rev at 336 (cited in note 26).

At one time, the DOI proposed that "willingness to accept may be the criterion most germane to natural resource damages, since the public has the property right to the injured natural resource." 51 Fed Reg 27,721 (1986). The DOI ultimately modified its position, stating that the application of WTA "can lead to more technical difficulties and uncertainties than the willingness-to-pay criterion." Id. The DOI concluded that WTA, for methodological reasons, might yield disproportionally high dollar assessments of natural resource damages. See Ohio, $880 \mathrm{~F} 2 \mathrm{~d}$ at $476-77 \mathrm{n} 82$.

8 In Camfield v United States, 167 US 518, 524 (1897), the Supreme Court granted the government's motion for summary judgment against a trespasser on federal land, relying on an analogy between the rights of the government as trustee of public lands and the rights of a private owner. This conception of public rights in national lands remains basic federal common law today in non-environmental cases. See United States $v$ Lawrence, 848 F2d 1502, 1510-12 (10th Cir 1988); United States v Ruckman, 806 F2d 1471, 1472-73 (10th Cir 1986); United States v Osterlund, 505 F Supp 165, 167 (D Colo 1981), aff'd 671 F2d 1267 (10th Cir 1982).

Federal common-law ownership analysis has been applied in circumstances involving pollution on public property. Before the enactment of environmental statutes, and their preemptive effects, see text accompanying notes 90-95, federal courts permitted the government to enjoin public-land pollution on a nuisance theory, implying that the government in effect "owns" natural resources. See United States v Luce, 141 F 385, 419 (CC 
currently dominant, natural resource valuation would be comparatively simple. In most cases of environmental damage, WTA surveys and other techniques which imply public ownership of natural resources would be the sole conceptually appropriate method of valuation. ${ }^{89}$

But several trends within environmental law have produced new concepts of natural resource ownership that increasingly obscure, or conflict with, traditional federal common law principles. These include: (i) preemption of federal common law by comprehensive environmental statutes such as the CWA, CERCLA, and the CAA; (ii) new conceptual challenges to the idea of public or government ownership of natural resources arising from complex environmental litigation; (iii) efforts to devise competing theories of property rights applicable to environmental law (generated in part by CV practitioners seeking to justify the use of WTP rather than WTA surveys); and (iv) the unsettled nature of the legal principles of federal land-use management. Thus, as environmental litigation expands, and rights issues become central to multi-million- or billion-dollar lawsuits, it is conceivable that conflicts over natural resource property rights will hamper the settlement of environmental disputes. Avoiding this result may require an explicit legislative effort to determine definitively the nature of property rights in environmental law contexts.

\section{A. Statutory Preemption of Federal Common Law}

In a series of decisions, the Supreme Court has held that comprehensive environmental statutes preempt federal common law. One opinion explained that the principles and remedies available before the enactment of the CWA were completely displaced after the legislation become effective. ${ }^{90}$ The lower courts

Del 1905) ("That the government, in the absence of a plain, adequate and complete remedy at law has a right to maintain an injunction bill to restrain a nuisance materially and injuriously affecting the occupancy of its own property there can be no doubt."); United States $v$ Atlantic-Richfield Co., 478 F Supp 1215 (D Mont 1979) (denying a motion to dismiss a government common-law nuisance action to enjoin emissions adversely affecting air quality in Glacier National Park and Flathead National Forest).

${ }^{89}$ Establishing that the government owns a resource, of course, does not definitively determine the average citizen's personal rights in the property, information necessary to select the appropriate form of $\mathrm{CV}$ analysis. The public's interest in a park, for example, is more akin to personal ownership than its interest in a top-secret military installation from which the vast majority of people are rigorously excluded. The relationship between public and individual interests and the choice of valuation techniques for less-freely substitutable goods therefore presents additional, and as yet unsettled, practical and legal problems which this Article does not address.

so In the leading case, City of Milwaukee $v$ Illinois, 451 US 304 (1981), the Supreme 
are now in the process of defining the extent of such statutory displacement. In general, they have held that the CWA and other water-pollution statutes preempt federal common law in the area of water pollution, but they remain split on the effects of the $\mathrm{CAA}^{91}$ The clear trend, however, is to find preemption wherever complicated statutory initiatives have been passed to govern a particular environmental issue.

While the Supreme Court's language appears absolute, the effects of preemption on federal common law principles are still unclear. $^{92}$ If the concept of displacement is taken literally, then federal common law amounts to little more than a stop-gap solution to federal problems. Once Congress legislates in a specific area, it nullifies the previously applicable legal principles and remedies created by federal judges, and the new statute alone controls all aspects of adjudication.

An alternative perspective is that while statutes prevail over federal common law when their intent to displace prior law is unmistakable, in most cases legislation relies on the context provided by existing legal principles. ${ }^{93}$ No statute can completely redefine or anticipate the various rights or consequences involved in complex social problems. Basic legal concepts developed through years of common law adjudication cannot, therefore, be swept away by legislation. Rather, they comprise the background principles that inform a statute. Federal common law therefore supplements and enriches a statutory regime even when preempted.

Court upheld the dismissal of a federal common-law nuisance action to enjoin water pollution in Lake Michigan, on the ground that the predecessor to the CWA completely preempted federal common law. Thus, "the need for the unusual exercise of lawmaking by federal courts" in fashioning remedies for water pollution harm vanished. Id at 314. A second decision, Middlesex County Sewerage Authority v National Sea Clammers Ass'n, 453 US 1 (1981), further extended the displacement doctrine. The Court suggested that if the language of a statute even implies that it pertains to matters formerly addressed by federal common law, common-law principles are preempted. Id at 21-22.

is Sea Clammers conclusively determined that the CWA and other water pollution statutes preempt federal common law. With respect to the CAA, however, the court in Atlantic-Richfield, $478 \mathrm{~F}$ Supp at 1219, found that the government's common-law rights were not preempted. However, in United States v Kin-Buc, Inc., 532 F Supp 699 (D NJ 1982), the court found that the CAA did preempt the federal common law of nuisance as applied to remedies for air pollution. Since Atlantic-Richfield was decided before the Supreme Court's preemption decisions, it is likely that the Kin-Buc position will ultimately prevail.

92 The following discussion relies on the analysis presented in William H. Rogers, Jr., 1 Environmental Law: Air and Water § 2.14 at 120-26 (West, 1986 \& Supp 1992).

93 Id at $120-121$. 
The complexities created by unsettled preemption questions greatly complicate the definition of property rights for natural resource valuation. If federal common law principles remain valid even after specific rules are preempted, then the traditional notion that the public "owns" natural resources should retain vitality. But if preemption literally sweeps aside all prior law, then the applicable property rights must be derived from sources other than federal common law. One possibility would be to examine the content and legislative history of the statutes themselves. This process, however, is always subject to uncertainty. No statute clearly defines natural resource property rights. ${ }^{94}$ In litigation contexts, support for a variety of positions will inevitably be found. Legislative history analysis is equally uncertain. The record of a bill's creation rarely provides unambiguous support for a specific legal interpretation. ${ }^{95}$ As a result, preemption obscures the question of public interests in natural resources.

\section{B. Conceptual Challenges to Traditional Public Natural Resource Rights Theories}

Novel, direct challenges to traditional public-ownership concepts present a second source of uncertainty regarding natural resource rights. Defendants in high-stakes environmental litigation increasingly attack basic common law concepts in an effort to undermine the legal support for environmental claims.

94 For example, it is plausible that the CWA and CERCLA imply public ownership of natural resources, because both statutes provide for damages, which are traditionally paid to owners. But it is also conceivable that a statute could create a damage remedy without also implying a right; damages remedies might be simply punitive, like criminal sanctions.

95 To illustrate, in a discussion of the non-compliance penalty of $\S 105$ of the CAA, the final joint report states:

[T] he polluter, after all, is using a public resource (air or water) for free. This use amounts to a subsidy by those (the public) who would otherwise be able to use it in an unpolluted state and must now either clean it up themselves, suffer its pollution, or abstain from using it. To shift the responsibility back to the polluter is to remove the hidden subsidy.

Clean Air Act Amendments of 1977, HR Rep No 95-294, 95th Cong, 1st Sess 73 (1977), reprinted in 1977 USCCAN 1077, 1151. This language appears to imply a public property right in the atmosphere.

At the same time, however, the CAA expressly did not authorize damage remedies, which had been included in the earlier CWA and CERCLA. See Currie, Air Pollution $\S$ 8.13 (cited in note 64). In the event of preemption, the lack of damage remedies could be taken as a reformation of basic property rights; although the public might be entitled to some compensation for the use of atmospheric resources by polluters, they would not own the resource, and thus would not be entitled to the higher valuation produced by WTA. 
For example, consider the disputes over insurance coverage under CERCLA. Extensive litigation has focused on whether standard comprehensive general liability ("CGL") clauses in insurance agreements apply to cleanup and response costs mandated by CERCLA. ${ }^{96}$ A typical CGL policy provides coverage for the legal obligations of an insured when paid as "damages" for injury to "property." While the major issue in CGL coverage cases has been whether response costs are "damages" within the meaning of the policy, insurers also have challenged whether pollution of natural resources can amount to "property" damage. ${ }^{98}$ Insurers have contended, for example, that government actions under CERCLA cannot be construed as suits for property damages because the notion of public ownership of natural resources is only a nineteenth-century "fiction." Whatever the public's interests might be, insurers argue, they do not comprise the same sorts of rights that accrue to private, fee-simple landowners. ${ }^{100}$

Currently, state and federal precedents tend to cut against the insurers' position. Challenges to the basic notion of public ownership rights have generally failed. ${ }^{101}$ But the volume and sophistication of such arguments are likely to grow as the relationship between property rights and the size of damage awards or cleanup valuations becomes increasingly obvious. Should new litigation over public property rights emerge, the possibility that conflicting decisions will appear in different state or federal jurisdictions will increase. This outcome would, at the very least, further obscure the legal doctrines defining public interests in natural resources.

96 For an excellent summary of the CGL issue in CERCLA litigation, see Kenneth S. Abraham, Cleaning up the Environmental Liability Insurance Mess, 27 Valp U L Rev 601 (1993). See also Note, CERCLA Cleanup Costs Under Comprehensive General Liability Insurance Policies: Property Damage or Economic Damage?, 56 Fordham L Rev 1169 (1988); AIU Insurance Co. v Superior Court, 51 Cal 3d 807, 799 P2d 1253 (1990); AerojetGeneral Corp. v Superior Court, 211 Cal App 3d 216 (1989), abrogated, 51 Cal 3d 807 (1990).

97 See, for example, AIU Insurance, $51 \mathrm{Cal} 3 \mathrm{~d}$ at 824-43.

${ }^{98}$ See id at 842-43; Aerojet, 211 Cal App 3d at 229-30.

${ }^{9}$ Aerojet, 211 Cal App 3d at 229.

100 Id.

101 For a summary of the outcomes of challenges to the notion of public ownership rights, see $A I U$ Insurance, $51 \mathrm{Cal} 3 \mathrm{~d}$ at 839 . For a review of decisions rejecting the argument that traditional common-law concepts of government ownership of natural resources are meaningless abstractions, see Aerojet, 211 Cal App 3d at 229-30 ("Unquestionably, the state and federal governments are third party property owners for purposes of insurance coverage. Pollution of the ground and river waters is damage to public property, as well as a direct injury to public welfare."). 


\section{The New Property Rights Approach}

CV researchers have themselves added to the uncertainty regarding public property rights. To justify their exclusive reliance on WTP, a small but influential group of CV practitioners has suggested a "new property rights approach" in which natural resources are likened to condominium common areas for which each user pays a fee. ${ }^{102}$ Proposed increases or decreases in commonly held goods of this sort, it is claimed, are properly conceived in terms of a WTP decision. ${ }^{103}$ For example, under the new property rights approach, WTP is the appropriate method for valuing Grand Canyon air quality because:

[T] he residents may possess the right to clean air but [if the source of pollution is owned by the public] they have to pay for it through higher electricity prices. Thus, the effective property right is WTP not WTA. ${ }^{104}$

So stated, the new property rights approach is unconvincing. The problem is that any statement in favor of WTP treatment can also be restated to support a WTA position. Since parallel rhetoric can be used to describe identical facts and yet produce opposite conclusions, the new property rights approach appears to be more an exercise in rhetoric than a principled analysis. The Grand Canyon visibility issue, for example, could be reformulated to fit a WTA perspective as follows:

The residents may have dirtier air than they have a right to but they are compensated for the dirtier air through lower electricity prices. Thus, they are effectively accepting money in compensation for dirtier air, making the effective property right WTA not WTP. ${ }^{105}$

102 An extensive discussion of the "new property rights approach" is found in Mitchell and Carson, Using Surveys to Value Public Goods at 38-41 (cited in note 5). The basic concept they propose is that for non-excludable public goods like air and water, consumers must either pay to maintain quality levels or, if they fail to make such payments, suffer decreases in the quality of the common amenities they enjoy. Id at 38-39.

${ }^{103}$ In Mitchell and Carson's analysis, WTP applies when a given level of public good quality is not currently available and the public wishes to obtain the higher quality. Id at 40. WTP is also applicable, they argue, when there is a proposed decrease in public good quality, since the consumers are already paying for the good on a regular basis. Id at 41 . A potential reduction in the good's quality is therefore best valued by asking consumers what they would be willing to pay to forego the reduction in the quality of the good and still be as well off as before. Id.

${ }_{104}$ See Carson, Constructed Markets at 130 (cited in note 8).

105 See RAND Report at 19 (cited in note 24). 
Consequently, the new property rights approach cannot settle the issue of whether WTP or WTA is the appropriate measure. It is simply an illogical attempt to reassign property rights in a fashion that would ease the difficult task of CV practitioners. The valid assignment of property rights remains a matter of law.

Still, the recent (and currently inadequate) attempts by some CV practitioners to justify their use of WTP surveys in settings where WTA would be appropriate could ultimately generate more sophisticated arguments that depart from traditional public-ownership concepts. As law-and-economics specialists begin to address issues of natural resource property rights, the complexity of the underlying legal analysis will almost certainly increase. In turn, the practical determination of the applicable rights may become more difficult.

\section{Federal Land-Use Doctrines}

Finally, the unsettled nature of federal land-use policies also complicates the definition of natural resource rights. The idea that WTA is the sole conceptually appropriate form of CV if the public "owns" national amenities far too simply equates proprietary interests with the legally significant rights required to perform valuations. Even in private contexts, landowners cede important property rights to others. In most communities, for example, utility companies possess easements to enter homesites for maintenance and safety reasons. Similarly, private parties may well enjoy certain commercial rights in public lands. If their reasonable exercise of such rights generates environmental harm, WTP questions may be appropriate to value damages or restoration costs. In effect, to prevent reasonable damage to public lands, the public must compensate rights holders for the loss of their commercial opportunities.

Federal land-management policies reflect a constant effort to balance public and private interests in natural resources. This balance can be struck in a number of ways. National parks most reflect the concept that federal lands are held in trust for the public; the parks are generally administered to preserve resources in a natural state for public enjoyment. ${ }^{106}$ At the other extreme are public lands dedicated almost entirely to commercial

106 George C. Coggins, Of Succotash Syndromes and Vacuous Platitudes: The Meaning of "Multiple Use, Sustained Yield" for Public Land Management, 53 U Colo L Rev 229, 235 (1982). For an analysis of the land-use principles that originally distinguished the various forms of federal land management programs, see id at 232-43. 
uses, such as those managed for domestic livestock grazing by the Bureau of Land Management ("BLM"). ${ }^{107}$ In between, national forests are managed according to a "multiple use, sustained yield" principle under which extensive oil, mineral, and timber harvesting, as well as ranching and recreation, are permitted..$^{108}$

The extensive, multi-faceted use of federal lands allows private interests to claim that they enjoy certain exploitation rights which the public may not curtail without providing compensation. Even in the national parks, for example, mining was still permitted in six cases as of 1982, and ranchers still retain grazing rights in at least one park. ${ }^{109}$ The likelihood of a constructive "pollution easement" arising from public-land exploitation is considerably greater on national forest or BLM property, where enormous timber, oil, mineral, and livestock projects are commonplace. ${ }^{110}$ In many cases, economic activity on public land is

107 Id at 237.

108 Id at 235, 251-57.

109 In the mid-1970s, continued mining activity in certain national parks was viewed as a threat to the integrity of unique national resources. In response, Congress enacted the Mining in the Parks Act of 1976, Pub L No 94-429, 90 Stat 1342 (1976), codified at 16 USC §§ 1901-1912 (1988 \& Supp IV 1992), which created a mandatory recording system to preclude mining claims in national parks. 16 USC $\$ 1907$. Nevertheless, six years later, mining still continued under valid claims in Crater Lake National Park, Coronado National Memorial, Death Valley National Monument, Glacier Bay National Monument, Mount McKinley National Park, and Organ Pipe Cactus National Monument. For an analysis of the recording provision and its effects, see generally Eva Novak, Mining and the National Park System, 2 J Energy L \& Pol 165, 171-78 (1982). In addition, to secure the requisite land to create the Great Basin National Park, located on the extreme eastern border of Nevada and Utah, ranchers with prior rights to graze on federal land were granted continuing access to national park forage, a situation unique in the national park system.

${ }^{110}$ George Coggins describes the significance of commercial exploitation of federal lands as follows:

The most striking statistic is that about half the Nation's commercial softwood sawtimber inventory is in the national forests alone ....

Timber and oil are prominent in the national resource picture, but the public lands contain many other scarce resources. Most remaining American big game animals, including some that are endangered, are found on federal land. And some, such as timber wolves, are found only there. Some fourteen percent of all cattle and sheep raised in the United States spend a part of their lives fattening on federal forage. The mineral wealth removed from lands now and formally federal is beyond calculation. As much as two-thirds of the total water yield in the eleven Western States originates in the federal reservations at higher elevations .... The recreational opportunities amenities offered by the hundreds of miles of whitewater, the ocean beaches, the scenic vistas and the reservoirs under federal control are beyond dollar valuation.

... Public land management is big business. The resource allocation decisions that are made concerning these federal lands can have life-or-death consequences for various operations that depend upon public land use, including cattle ranches, saw- 
also regulated by specialized statutes, such as the 1955 Surface Resources Act ${ }^{111}$ or the Multiple Mineral Development Act, ${ }^{112}$ which may create additional private rights in public lands. ${ }^{113}$ Indeed, private ranchers have in fact secured judicial recognition, based on "statutory preference and agency deference," for their rights to forage on BLM land. ${ }^{114}$

The concept that multiple uses may require at least some permissible natural resource degradation, and that the public should have to pay to protect national amenities from such harm, could also extend to developments outside of federal lands. For example, many perceive a need to manage whole ecosystems, rather than simply the more limited lands contained in formal park or forest boundaries. ${ }^{115}$ But efforts to force administrative agencies to address ecosystem management issues, even when treasured national park integrity is at issue, have been generally unsuccessful to date. ${ }^{116}$

This precedent could support claims that an implicit tradeoff between essential economic activities and public rights in natural resources is an inherent part of American law. Alternatively, it might be argued that by failing to restrain environmental encroachments on public lands, the government has in effect waived

mills, tourist facilities, hunting outfitters, and the like.

Coggins, 53 U Colo L Rev at 233-34 (cited in note 106). For a review of the basic principles of multiple-use management and case studies, see id at 240-50.

111 Pub L No 84-167, 69 Stat 368 (1955), codified at 30 USC $\S \S 611-12$ (1988).

112 Pub L No 83-585, 68 Stat 709 (1954), codified as amended at 30 USC $\S \S 521-31$ (1988).

${ }^{113}$ See Coggins, 53 U Colo L Rev at 278.

114 ,See id at 236. There are no corresponding "rights" to national forest resources. Id.

115 An ecosystem is often defined as "a unit made up of all the living and nonliving units of a particular area that interact and exchange materials with each other." Robert B. Keiter, Taking Account of the Ecosystem on the Public Domain: Law and Ecology in the Greater Yellowstone Region, 60 U Colo L Rev 923, 929 (1989), citing The Facts on File Dictionary of Biology 97 (1988). For a summary of the concept of the ecosystem and its application to public land management policy, see 60 Colo L Rev at 929-43.

116 See generally id at 944-51; Comment, Protecting National Parks from Developments Beyond Their Borders, 132 U Pa L Rev 1189, 1189-1201 (1985). The Comment also discusses the issue of ecosystem management in the context of federal common-law preemption. Id at 1191-97. It argues that while the Supreme Court's preemption decisions have largely eroded the federal common law of nuisance used to redress extraterritorial harms to national parks or forests, "a more general body of federal common law of nuisance may remain intact," serving as a deterrent to those planning environmentally harmful activities on lands adjacent to parks and forests. Id at 1195. See also A. Dan Tarlock, Local Protection of Biodiversity: What Is Its Niche?, $60 \mathrm{U}$ Chi L Rev 555, 603-605 (1993) (suggesting that local governments may supplement federally imposed standards conserving wildlife and other environmental resources). 
its right to enforce the environmental laws. ${ }^{117}$ If so, WTP would be proper for natural resource valuation studies.

In summary, natural resource rights analysis is complicated by several doctrinal, theoretical, and strategic litigation concerns. In practice, because defining public interests in national amenities will increasingly be required to effectuate federal environmental protection programs, rights issues threaten to overwhelm environmental law. As the near decade-long struggle over the DOI valuation regulations illustrates, environmental disputes encourage no-holds-barred litigation. If natural resource rights analysis is left to the judicial process, significant delays and costs may preclude effective environmental protection.

Legislative intervention may be necessary to avoid this outcome. Rather than endure years of contention over the effects of preemption on federal common law, or rely on the implications of the language of the CWA, the CAA, or CERCLA to define property rights, Congress could simply pass legislation defining the applicable property rights for natural resource valuation. If it is desirable to affirm the public ownership concepts embedded in federal common law, Congress should require that estimates of damages reflect the public's property rights. In many cases this would imply that WTA questions would be the conceptually appropriate method for making valuations. Alternatively, Congress could declare that these natural resources should not be considered to be owned by the public, making WTP questions the conceptually correct form in most natural resource damage disputes. In either case, a definitive determination of natural resource property rights would avoid the lengthy litigation that would otherwise almost certainly result.

\section{CONCLUSION: THE LAW AND ECONOMICS OF LESS-SUBSTITUTABLE Goods}

We have argued that the valuation of goods having no close substitutes, including many disputed natural resources, can be highly sensitive to the definition of property rights. A growing

117 Environmental law contains concepts that could support a litigant's effort to raise a waiver defense. CERCLA actions, for example, can be defended on the grounds that a discharge took place as permitted under several environmental, chemical, regulatory, or other federal statutes. 42 USC \$ 9607(j). See also Andrew J. Simons and James H. Wicks, Natural Resource Damages Under CERCLA: Here They Come, Ready or Not, 63 St John's L Rev 801, 816-17 (1989). If the exercise of private statutory rights in public lands predictably causes some environmental harm, a waiver defense may arise. 
number of disputes involve public environmental goods that are not valued through standard market mechanisms or other observable behaviors of the public; CV techniques or other similar surveys are the only viable methods for valuing these goods. Further, unlike situations involving highly substitutable goods, it is not possible to measure properly the value of the good until the property rights to it have been established. Defining such rights, however, is complicated by preemption of prior legal doctrines and increasingly sophisticated challenges to traditional concepts of public resource ownership. The law-and-economics principles applicable to less-substitutable goods have significant theoretical and practical ramifications for America's environmental protection efforts.

These principles may also affect American jurisprudence more generally. First, they may reshape basic theories of value. As we have discussed, economists have been forced to devise valuation methodologies that measure more than market values alone. There seems little justification not to apply the same techniques to other legal disputes. It is reasonable to suppose that most amenities are valued by their owners along a range defined by pure commodity goods (which are freely substitutable) at one extreme and unique natural resources (which are not) at the other. Just as with unique natural resources, valuing goods located in the less-substitutable spectrum should involve measuring the non-market premium values they possess. To this end, it will be necessary to build appropriate non-market measurement methods like CV to reach principled conclusions in non-environmental legal disputes that involve unique goods.

It will also be necessary to reconsider the role of courts in defining economic rights. Applying the restrictive assumptions required by conventional analysis, economists have taught adjudicators that they need not actually determine the rights of the parties to value economic damages. Instead, they can look to market values; application of other measures by government or the courts would only interfere with a valuation presented by efficient market mechanisms. But for less-substitutable goods, market valuation fails, and damages cannot be measured until property rights are defined. While in some cases deciding such rights should not be difficult, in others the complexity that currently afflicts natural resource rights analysis may recur. ${ }^{118}$

${ }^{118}$ For example, torts involving intellectual property could well require extremely complex derivations of applicable rights. In addition to damages from the loss of potential 
In environmental law, the need to define property rights in legal disputes may necessitate a political solution. Ultimately, the role of legal and political decisionmakers in American law would likely be quite different than conventional legal and economic studies assume. Consequently, disputes involving less-substitutable goods could stimulate a widespread reconsideration of the relation between property rights and economic allocation. Many may resist this process, preferring the methodological purity and comparative simplicity offered by conventional analysis. These traits are certainly attractive. But should environmental law precedents be extended to other cases, as is likely, the change may be inevitable. The theoretical and practical problems now surrounding CV natural resource studies might therefore presage future challenges of deriving the law and economics of all less-substitutable goods.

market or "use value" of an intellectual good, it is likely that the "owners" of ideas derive substantial non-use/non-market utility from their rights to exploit the concepts they develop. Measuring harm to such goods also involves non-use values. But in order to value non-use utilities associated with intellectual property, it is first necessary to precisely identify the character of ownership rights of such goods.

Defining rights to intellectual property, however, has often confounded commentators and courts. Similar problems may develop in other instances in which measuring the non-use values of less substitutable goods is necessary to resolve legal disputes. 